\title{
CLINICAL AND HISTOLOGICAL CHARACTERISTICS OF HIV AND HEPATITIS C VIRUS-CO-INFECTED PATIENTS IN BRAZIL: A CASE SERIES STUDY
}

\author{
Maria Cássia MENDES-CORREA(1), Azzo WIDMAN(2), Maria Luiza Paes BRUSSI(1), Cristina Fátima GUASTINI(1), Norma de Paula CAVALHEIRO(3),
} Carlos Eduardo MELO(3), Antonio Alci BARONE (3) \& Reinaldo José GIANINI(4)

\begin{abstract}
SUMMARY
Hepatitis $\mathrm{C}$ virus (HCV) is an important factor contributing to morbidity and mortality in patients co-infected with HIV and $\mathrm{HCV}$. In addition, liver biopsy is an important tool in the clinical management of these patients. Although liver biopsy is controversial, it is recommended for all patients. Data regarding the clinical and histological characteristics of these patients are scarce not only in Brazil but in Latin America as a whole. With the goal of better understanding these characteristics and the benefit of liver biopsy indications in this disease setting, data collected from 234 patients followed from 1996 to 2004 at Casa da AIDS, São Paulo, were analyzed. The following variables were extracted from the patients' medical files at the time of liver biopsy: sex, age, hepatitis C infection risk factors, hepatitis $\mathrm{C}$ infection duration, ALT levels, $\mathrm{CD} 4^{+} \mathrm{T}$ cell counts, history of alcohol abuse, history of antiretroviral therapy, HCV genotype, and liver histological alterations. Conclusions: 1 - Hepatitis C virus 1 and 3 were the most frequently identified genotypes and were diagnosed in $72 \%$ and $25.5 \%$ of cases respectively; $\mathbf{2}$ - Structural liver alterations were found to be mild or absent in $48.2 \%(113 / 234)$ of the analyzed patients; 3 - Fifty-three patients (23\%) had normal ALT levels and 4 - Significant liver architectural changes (F2-F3) were evident in $22.5 \%$ of the patients with normal ALT levels.
\end{abstract}

KEYWORDS: Hepatitis C; HIV; Liver biopsy; Brazil; Genotype.

\section{INTRODUCTION}

As hepatitis $\mathrm{C}$ virus (HCV) and HIV share the same mechanisms of infection, co-infection with these two viruses is very common and occurs in at least $30 \%$ of HIV-infected patients. Hepatitis C has become an important cause of morbidity and mortality among HIV patients ${ }^{1,17,23}$. Therefore, the adequate management of $\mathrm{HCV}$ is now a subject of great interest.

The role of liver biopsies in patient care is controversial ${ }^{26,27}$. Some clinicians believe that the indication for liver biopsy is optional and only necessary if specific HCV treatment is recommended. Other clinicians dispute this position and argue that the biopsy procedure might offer essential information for patient care.

It is also uncertain whether liver biopsy should be recommended for $\mathrm{HCV}$ patients with a normal alanine aminotransferase (ALT) level ${ }^{26}$.

In Brazil, the prevalence of HCV infection among HIV infected patients ranges from $17 \%$ to $53 \%$ depending on the study ${ }^{8,12,15,18,25}$. Nonetheless, clinical and histological data on these patient characteristics are limited.
This study was conceived with the intention to further the knowledge of the clinical and histological aspects of hepatitis $\mathrm{C}$ virus infection among HIV-infected patients.

\section{PATIENTS AND METHODS}

The present study included HIV-HCV co-infected patients under medical care at Casa da AIDS, Hospital das Clinicas, University of São Paulo Medical School. Casa da AIDS (AIDS' Home) is a specialized medical center devoted to the care of HIV-infected patients. It is currently in charge of approximately 3,500 patients.

In 1996, a group specifically directed towards the medical attention of HIV, HCV and/or HBV-co-infected patients was created at Casa da AIDS. All patients under this group's medical care from October 1996 to October 2004 were initially included in this study.

For HIV diagnosis, an enzyme immunosorbent assay (EIA) was used followed by confirmation with commercial enzyme-linked immunosorbent assays (Organon Technika, Tournault, Belgium; and Embrabio, São Paulo, Brazil). Specimens that tested positive after EIA and those with discordant or indeterminate results were confirmed by 


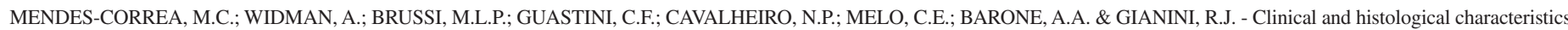
of HIV and hepatitis C virus-co-infected patients in Brazil. A case series study. Rev. Inst. Med. trop. S. Paulo, 50(4): 213-217, 2008.

Western blotting analysis. EIA was also used for hepatitis B diagnosis, specifically to determine $\mathrm{HbsAg}$ positivity, $\mathrm{HBs}$ antibodies, $\mathrm{HBc}$ total antibodies, $\mathrm{HBeAg}$, and $\mathrm{HBe}$ antibodies. Third-generation EIAs for $\mathrm{HCV}$ antibodies were used in hepatitis $\mathrm{C}$ analysis. To test HCV RNA presence, nested polymerase chain reactions were employed. The genotyping was performed by a reverse hybridization assay, the Line Probe Assay (INNO-LiPA HCV / VERSANT ${ }^{\mathrm{TM}}$ HCV Genotype Assay - Bayer Corporation, Tarrytown, NY, USA), based on hybridization of labeled PCR amplification products to specific probes directed against the variable regions of the 5' NCR of the genotypes 1, 2, 3, 4, 5, 6 and $1 \mathrm{a}, 1 \mathrm{~b}, 2 \mathrm{a} / 2 \mathrm{c}, 2 \mathrm{~b}, 5 \mathrm{a}$ and $6 \mathrm{a}$ subtypes. All patients were confirmed to have HIV and HCV infection. Every patient who underwent liver biopsy had reagent RNA testing for $\mathrm{HCV}$ using the PCR technique.

During the period mentioned above, 600 patients were followed. For the purpose of the study's analysis, patients whose clinical and histological data were available were identified. Those who had not undergone a liver biopsy were not included. The same option was applied to those diagnosed with hepatocellular carcinoma, those who were $\mathrm{AgHBs}$ positive, individuals with a history of interferon or ribavirin use before the biopsy and cases in which medical information was incomplete.

Liver biopsy recommendation for the study patients was based on the significance of liver biopsy in evaluating HCV-related hepatopathy and for the assessment of specific treatment necessity. Even though there was no treatment indication at the time of biopsy for 49 patients, the procedure was carried out according to the judgement of the attending physician, as the CD4+ T cells counts were less than 200. Patients with normal liver enzyme levels and $\mathrm{CD} 4^{+} \mathrm{T}$ cell counts higher than 200, also underwent biopsy, following a clinical protocol approved by the institution's Ethics Committee.

Histological analysis was carried out by Hospital das Clinicas Pathology Department using criteria validated by the Brazilian Hepatology and Pathology Society ${ }^{6}$. Liver aggression staging followed a necroinflamatory activity score ranging from 0 to 4 and a liver architectural change score also ranging from 0 to 4 .

Analyzed factors: Medical records were reviewed for this study by three staff physicians. Patients from whom the following information was retrieved were included in the analysis: demographic characteristics (age; sex), HIV and HCV infection risk factors, alcohol abuse history, antiretroviral therapy history, $\mathrm{CD}^{+} \mathrm{T}$ cell counts and ALT levels at the time of biopsy, hepatitis $\mathrm{C}$ infection span (in cases of viral parenteral transmission) and $\mathrm{HCV}$ genotype. Variable response rates were greater than $90 \%$ throughout the duration of the medical record research.

Information regarding alcohol abuse was included if ingestion of quantities $\geq 50 \mathrm{~g}$ of alcohol per day for $\geq 06$ months occurred at any time prior to liver biopsy. Information on antiretroviral drug therapy antecedent was considered positive when therapy was reported by the patients as having happened at any time before liver biopsy for at least six consecutive months. CD4 ${ }^{+} \mathrm{T}$ cell count levels contemporary to the biopsy were registered. Values from six months prior to six months after the procedure were accepted. If more than one value was found, the arithmetic medium of the results was taken into consideration. ALT levels from the same period were also found and registered. If more than one value was identified, the arithmetic medium was taken into consideration.

We also included patients with persistently normal ALT levels (i.e., subjects with at least three consecutive normal ALT determinations during a pre-biopsy follow-up of 12 months).

This study was carried out with the approval of the Ethics and Research Committee of Hospital das Clinicas, University of São Paulo Medical School.

\section{RESULTS}

Six hundred HIV-HCV-co-infected patients followed by the viral hepatitis group at Casa da AIDS were submitted for analysis. Three hundred sixty-five patients were excluded from the study for the following reasons: absence of liver biopsy (287), hepatocellular carcinoma diagnosis (2), positive serology for AgHBs (26) and incomplete clinical data (50).

Two hundred thirty-four patients (234) were thus further analyzed in this study having complete clinical data (at least six of the eight analyzed factors) and liver biopsy information. Table 1 summarizes the clinical and demographic characteristics, while Tables 2, 3 and 4 show histological findings.

Study Population: Most patients were male (74.3\%) and former IDUs $(50.8 \%)$. Up to $62.8 \%$ of patients admitted prior high alcohol intake. The median age at the time of liver biopsy was 39 years $(39 \pm 7)$.

Table 1

Clinical data at the time of biopsy

\begin{tabular}{lc}
\hline Age, years, Mean, SD & $39 \pm 7$ \\
Sex, male & $174(74.3 \%)$ \\
CD4 ${ }^{+}$T cell count, cells/mm ${ }^{3}$ Median \pm SD & $389 \pm 241$ \\
ARV therapy history - Yes & $195(83.3 \%)$ \\
ARV therapy history - No & 20 \\
ARV therapy history - Unavailable & 19 \\
Alcohol consumption history - Yes & $147(62.8 \%)$ \\
Alcohol consumption history - No & 68 \\
Alcohol consumption history - Unavailable & 19 \\
HCV infection risk factors & \\
Endovenous drug use & $119(50.8 \%)$ \\
Blood transfusion & 04 \\
Percutaneous accident & 02 \\
Other, non-parenteral & 63 \\
Unavailable & 20 \\
HCV genotype & $121(72 \%)$ \\
Genotype 1 & $04(2.3 \%)$ \\
Genotype 2 & $43(25.5 \%)$ \\
Genotype 3 & \\
Total & 66 \\
Unavailable & \\
ALT levels & \\
Normal & $53(23.9 \%)$ \\
\hline
\end{tabular}




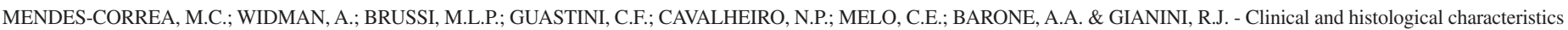
of HIV and hepatitis C virus-co-infected patients in Brazil. A case series study. Rev. Inst. Med. trop. S. Paulo, 50(4): 213-217, 2008.

Table 2

Liver histological alterations for 234 HIV-hepatitis C virus co-infected patients
Table 3

Liver histological changes among patients with normal ALT levels

\begin{tabular}{llll}
\hline $\begin{array}{l}\text { Number of biopsies } \\
\text { Hepatitis }\end{array}$ & 234 & & \\
fibrosis stage & & $\begin{array}{l}\text { Hepatitis } \\
\text { activity grade }\end{array}$ \\
F0-F1 & $82(35 \%)$ & A0-A1 & $46(19.6 \%)$ \\
F2 & $51(21.7 \%)$ & A2 & $66(28.2 \%)$ \\
F3 & $39(16.6 \%)$ & A3 & $65(27.7 \%)$ \\
F4 & $20(8.5 \%)$ & A4 & $15(6.4 \%)$ \\
Reactional liver* & $31(13.2 \%)$ & & \\
Other diagnosis & $11(4.7 \%)$ & & \\
\hline
\end{tabular}

*Reactional liver: borderline histological pattern set between normality and chronic hepatitis, and characterized by a staging score of 0 or 1 , and a periportal activity score of 0 .

\begin{tabular}{|c|c|c|c|}
\hline Number of biopsies & 53 & & \\
\hline Hepatitis & & Hepatitis & \\
\hline fibrosis stage & & activity grade & \\
\hline F0 & $07(13.2 \%)$ & A0 & $02(3.7 \%)$ \\
\hline $\mathrm{F} 1$ & $20(37.7 \%)$ & A 1 & $12(22.6 \%)$ \\
\hline $\mathrm{F} 2$ & $09(16.9 \%)$ & $\mathrm{A} 2$ & $17(32 \%)$ \\
\hline F3 & $03(5.6 \%)$ & A3 & $08(15 \%)$ \\
\hline F4 & ZERO & A4 & ZERO \\
\hline Reactional liver & $14(26.4 \%)$ & & \\
\hline Other diagnosis & ZERO & & \\
\hline
\end{tabular}

Table 4

Liver histological changes grouped according to $\mathrm{CD}^{+} \mathrm{T}$ cell levels

\begin{tabular}{llllll}
\hline Number of biopsies* & 11 & 38 & 56 & 56 & 54 \\
\hline CD4 & $<100$ & $100-200$ & $201-349$ & $350-500$ & $17(30.3 \%)$ \\
F3-F4 & $2(18 \%)$ & $11(28.9 \%)$ & $13(23.2 \%)$ & 4 & $13(24 \%)$ \\
Reactional liver & & 8 & 11 & 1 & 5 \\
Other diagnosis & & 1 & 2 & \\
Steatosis & 3 & 2 & & \\
Mycobacteriosis & 1 & & & \\
Histoplasmosis & & & & \\
\hline
\end{tabular}

*Number of biopsies for which CD4 cell count levels were known: Total $=215$

Most patients (83\%) were taking HAART. The median CD4+ T cell count at the time of liver biopsy was 389 cells $/ \mathrm{mm}^{3}(\mathrm{SD} \pm 241)$, and 49 patients had a CD4+ T cell count of $<200$ cells $/ \mathrm{mm}^{3}$.

Seventy-six per cent of patients (181/234) had abnormal ALT values. ALT levels were on average two and a half times superior to the limits of normality.

The distribution of genotypes was as follows: $121(72 \%)$ of patients were infected with genotype 1, 4 (2.3\%) with genotype 2, $43(25.5 \%)$ with genotype 3 . None of the patients had mixed genotypes (Table 1).

Liver Biopsy: The distribution of patients according to liver fibrosis was as follows: F0-F1 in 82 patients (35\%), F2 in 51 patients $(21.7 \%)$, $\mathrm{F} 3$ in 39 patients $(16.6 \%)$ and $\mathrm{F} 4$ in 20 patients $(8.5 \%)$.

Reactional liver was observed in 31 patients (13.2\%) and other histopathological diagnoses were observed in 11 patients $(4.7 \%)$ (Table 2).

Among patients with normal ALT levels, the distribution of patients according to liver fibrosis was as follows: F0 in seven patients (13.2\%), $\mathrm{F} 1$ in 20 patients $(37.7 \%), \mathrm{F} 2$ in nine patients $(16.9 \%)$, and F3 in three patients $(5.6 \%)$. Reactional liver was observed in 14 patients $(26.4 \%)$ (Table 3).
Liver biopsy led to the diagnosis of other hepatic diseases in 11 cases (11/234) (Table 4). Five of the hepatic disease cases were affected by liver steatosis, five by liver mycobacteriosis, and one by liver histoplasmosis.

\section{DISCUSSION}

The results of this study demonstrate that liver biopsy was able to not only stage chronic hepatitis caused by HCV but also to diagnose other diseases in $4.7 \%$ of the analyzed cases (Table 2/Table 4). This study also demonstrates that even patients with normal hepatic enzyme levels might have advanced liver disease (Table 3 ).

The medical literature has not reached a consensus on whether liver biopsy should be recommended for every patient, especially when the HIV-HCV-co-infected population is in question ${ }^{26,27}$. In our experience, liver biopsy is recommended as a routine for every patient, including those who have normal hepatic enzyme levels. In Brazil, there are no data available concerning histological characteristics of these patients and evaluation of the actual necessity of biopsy.

Our data demonstrate that $113(48.2 \%)$ of the analyzed patients had absent or minimal hepatic disease (F0-F1) (Table 2). These numbers convey a higher percentage of patients with mild liver disease compared to those found in similar studies. Such studies report from 35 to $43 \%$ 


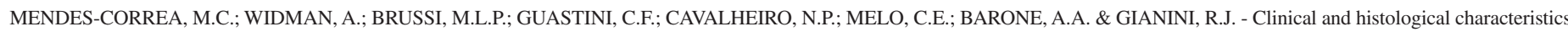
of HIV and hepatitis C virus-co-infected patients in Brazil. A case series study. Rev. Inst. Med. trop. S. Paulo, 50(4): 213-217, 2008.

of mild disease cases among biopsied patients ${ }^{9,10,14,20}$. However, the present study included patients with normal hepatic enzyme levels, which sets it apart from other studies and might account for the differences in results.

In our analysis, $25 \%$ of the patients suffered from severe liver aggression (F3-F4) (Table 2).

Cirrhosis is the final stage of liver fibrosis progression. Evolution from infection to cirrhosis is faster in HIV-HCV-co-infected patients compared to patients who are only infected with $\mathrm{HCV}^{11,26}$. Nonetheless, there are great variations in the length of time necessary for such progression and many contributing factors. Some of these factors are well known: time of infection, age, male gender, alcohol abuse, HIV co-infection, and low $\mathrm{CD}^{+} \mathrm{T}$ cell counts. Metabolic conditions such as liver steatosis, excess weight and diabetes also appear to contribute to liver fibrosis progression.

The association between these variables and advanced fibrosis was not analyzed in this study. However, it was observed that there was not a significant difference in the incidence of these factors when patients were grouped according to their $\mathrm{CD}^{+} \mathrm{T}$ cell count (Table 4).

Concerning the analysis of ALT levels at the time of biopsy, it is relevant to note that most patients $(76.1 \%$ ) (Table 1) had increased enzyme values that were on average two and a half times higher than the limits of normality.

Regarding the histological findings among patients with normal ALT levels, it was observed that significant liver architectural changes (F2-F3) were evident in $22.5 \%$ of the patients with normal ALT levels. Among the patients with significant liver architectural changes three patients $(5.6 \%)$ had advanced fibrosis (F3). It was also observed that eight patients $(15 \%)$ had advanced necroinflammatory liver aggression (A3) (Table 3).

We believe that liver biopsy should be recommended for HIV-HCVco-infected patients regardless of whether hepatic enzymes are altered. Our results demonstrating that severe liver disease occurs even among patients with normal alanine aminotransferase levels are supported by other recent work with similar conclusions ${ }^{5,7,28}$.

Liver biopsy led to the diagnosis of other hepatic diseases in 11 cases (11/234) (Table 4). Five of these cases were affected by liver steatosis, five by liver mycobacteriosis, and one by liver histoplasmosis. In the aforementioned cases, liver biopsy served as a diagnosis tool, allowing for the detection of unknown conditions. It should be pointed out that mycobacteriosis and histoplasmosis were diagnosed among patients with severe immunological compromise and $\mathrm{CD} 4^{+} \mathrm{T}$ cell counts lower than 200 (Table 4). These liver biopsy recommendations were based on the fact that in the course of diagnostic investigation elevated cellular and canalicular enzyme levels (ALT, AST, GGT and alkaline phosphatase) were observed in the presence of serum HCV-RNA.

Of the identified HCV genotypes, genotype 1 was the most frequently identified, corresponding to $72 \%$ (121) of the cases. Genotype 3 was found in 43 cases $(25.5 \%)$ and genotype 2 in four cases $(2.3 \%)$ (Table 1$)$. Similar results have been reported by other studies that evaluated the same parameters among coinfected patients ${ }^{21,22,24}$. Our findings are also consistent with those described in a study evaluating HCV genotypic distribution among mono-infected patients in Brazil $1^{2,3,4,16}$.

Intravenous drug use was the most frequently reported $\mathrm{HCV}$ infection risk factor, which is supported by other studies on this topic ${ }^{13}$.

It is our belief that our study strengthens the case for liver biopsy as an important tool in the management and treatment recommendation for hepatitis $\mathrm{C}$ in our setting.

Almost half of the patients (48.2\%) had mild liver disease at biopsy. In our opinion, treatment recommendation for these patients should be individualized with the objective of reducing iatrogenic complications and treatment costs.

Hepatitis $\mathrm{C}$ treatment is mandatory for those who have clear clinical indications and treatment introduction at the appropriate time undoubtedly prevents complications such as liver failure, cirrhosis and hepatocellular carcinoma. Nevertheless, HCV treatment also involves the risk of severe adverse effects, potential drug interactions and a much higher financial burden. As mentioned before, HCV treatment recommendations should be decided on a case-by-case basis to improve the chances of success.

In addition to what has been described here, liver biopsy might serve as a diagnostic tool for other diseases that affect HIV-HCV coinfected patients. It might also provide an important accessory for clinical monitoring during future treatments, such as during chronic hepatitis re-treatment.

\section{RESUMO}

\section{Características clínicas e histológicas de pacientes co-infectados pelo HIV e vírus da hepatite $\mathrm{C}$ no Brasil: estudo de uma série de casos}

A infecção causada pelo vírus da hepatite C (VHC) constitui importante causa de morbidade e mortalidade entre pacientes coinfectados pelo HIV e VHC. A indicação da realização de biópsia hepática nesses pacientes é controversa, podendo constituir importante ferramenta no manejo clínico desses pacientes. São escassos os dados relativos às características clínicas e histopatológicas dos pacientes co-infectados no Brasil e em toda a América Latina. Com o objetivo de analisar as características clínicas e histopatológicas em coinfectados e avaliar os benefícios da realização de biópsia hepática nesse grupo de pacientes, analisamos dados relativos a 234 pacientes acompanhados na Casa da AIDS, São Paulo, de 1996 a 2004. A partir de informações obtidas em prontuários, foram analisadas as seguintes variáveis relativas aos pacientes, coletadas à época da realização da biópsia hepática: gênero, idade, fatores de risco para a transmissão da hepatite $\mathrm{C}$, tempo estimado de infecção pelo VHC, níveis séricos de ALT, contagem de células CD4, antecedentes relativos ao uso de álcool, antecedente de uso de terapia antiretroviral, genótipo de VHC e alterações histológicas obtidas através da biópsia hepática. Conclusões: 1- Os genótipos 1 e 3 foram os mais freqüentes nessa população, representando cerca de $72 \%$ e $25,5 \%$ dos casos analisados 


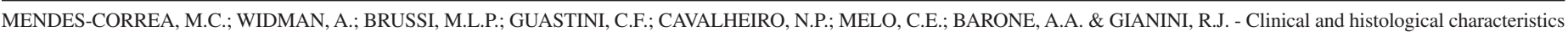
of HIV and hepatitis C virus-co-infected patients in Brazil. A case series study. Rev. Inst. Med. trop. S. Paulo, 50(4): 213-217, 2008.

respectivamente; 2 - Alterações estruturais hepáticas leves ou ausentes foram observadas em 48,2\% dos pacientes (113/234); 3- Cinqüenta e três pacientes $(23 \%)$ apresentaram níveis de ALT persistentemente normais; 4- Alterações estruturais significativas (F2-F3) foram observadas em 22,5\% entre pacientes com níveis de ALT persistentemente dentro da normalidade.

\section{REFERENCES}

1. BICA, I.; McGOVERN, B.; DHAR, R. et al. - Increasing mortality due to end-stage liver disease in patients with HIV infection. Clin. infect. Dis., 32: 492-497, 2001.

2. BUSEK, S. \& OLIVEIRA, G. - Molecular epidemiology of the hepatitis C virus in Brazil. Genet. Molec. Res., 2: 117-123, 2003.

3. CAMPIOTTO, S.; PINHO, J.R.; CARRILHO, F.J. et al. - Geographic distribution of hepatitis C virus genotypes in Brazil. Braz. J. med. biol. Res., 38: 41-49, 2005.

4. FOCACCIA, R.; BARALDO, D.C.; FERRAZ, M.L. et al. - Demographic and anthropometrical analysis and genotype distribution of chronic hepatitis $\mathrm{C}$ patients treated in public and private reference centers in Brazil. Braz. J. infect. Dis., 8: 348355, 2004.

5. FONQUERNIE, L.; SERFATY, L.; CHARROIS, A. et al. - Significance of hepatitis C virus coinfection with persistently normal alanine aminotransferase levels in HIV-1infected patients. HIV Med., 5: 385-390, 2004

6. GAYOTTO, L.C.C. \& COMITÊ SBP/SBH - Visão histórica e consenso nacional sobre a classificação das hepatites crônicas. GED, 19: 137-140, 2000.

7. GONZALES, S.A.; LIU, R.C.; EDLIN, B.R. et al. - HIV/hepatitis C virus-coinfected patients with normal alanine aminotransferase levels. J. acquir. immune Defic. Syndr., 41: 582-589, 2006.

8. MARINS, J.R.; BARROS, M.B.; MACHADO, H. et al. - Characteristics and survival of AIDS patients with hepatitis C: the Brazilian National Cohort of 1995-1996. AIDS, (Suppl 4): S27-S30, 2005.

9. MARKS, K.M.; PETROVIC, L.M.; TALAL, A.H. et al. - Histological findings and clinical characteristics associated with hepatic steatosis in patients coinfected with HIV and hepatitis C virus. J. infect. Dis., 192: 1943-1949, 2005.

10. MARTIN-CARBONERO, L.; BENHAMOU, Y.; PUOTI, M. et al. - Incidence and predictors of severe liver fibrosis in human immunodeficiency virus-infected patients with chronic hepatitis C: a European collaborative study. Clin. infect. Dis., 38: 128133, 2004.

11. MARTINEZ-SIERRA, C.; ARIZCORRETA, A.; DÍAZ, F. et al. - Progression of chronic hepatitis $\mathrm{C}$ to liver fibrosis and cirrhosis in patients coinfected with hepatitis $\mathrm{C}$ virus and HIV. Clin. infect. Dis., 36: 491-498, 2003.

12. MENDES-CORRÊA, M.C.J.; BARONE, A.A.; CAVALHEIRO, N.P.; TENGAN, F.M. \& GUASTINI, C. - Prevalence of hepatitis B and C in the sera of patients with HIV infection in São Paulo, Brazil. Rev. Inst. Med. trop. S. Paulo, 42: 81-85, 2000.

13. MENDES-CORREA, M.C; BARONE, A.A.; GIANINI, R.J. - Risk factors associated with hepatitis $\mathrm{C}$ among patients co-infected with human immunodeficiency virus: a case-control study. Amer. J. trop. Med. Hyg., 72: 762-767, 2005.
14. MERCHANTE, N.; MACIAS, J.; PALACIOS, R.B. et al. - Prevalence of non-significant liver fibrosis and rate of fibrosis progression in HIV/hepatitis C virus- co-infected patients: still a role for liver biopsy? AIDS, 18: 1746-1748, 2004.

15. MONTEIRO, M.R.; DO NASCIMENTO, M.M.; PASSOS, A.D. \& FIGUEIREDO, J.F. Hepatitis C: prevalence and risk factors among patients with HIV/AIDS in Belém Pará, in Brazilian Amazon. Rev. Soc. bras. Med. trop., 37 (suppl. 2): 40-46, 2004

16. OLIVEIRA, M.L.; BASTOS, F.I.; SABINO, R.R. et al. - Distribution of HCV genotypes among different exposure categories in Brazil. Braz. J. med. biol. Res., 32: 279 $282,1999$.

17. PALELLA Jr., F.J.; BAKER, R.K.; MOORMAN, A.C. et al. - Mortality in the highly active antiretroviral therapy era: changing causes of death and disease in the HIV outpatient study. J. acquir. Immun. Defic. Syndr., 43: 27-34, 2006.

18. PAVAN, M.H.; AOKI, F.H.; MONTEIRO, D.T. et al. - Viral hepatitis in patients infected with human immunodeficiency virus. Braz. J. infect. Dis., 7: 253-261, 2003.

19. PUOTI, M.; BONACINI, M.; SPINETTI, A. et al. - Liver fibrosis progression is related to CD4 depletion in patients coinfected with hepatitis C virus and HIV. J. infect. Dis., 183: 134-137, 2001.

20. QUEREDA, C.; MORENO, S.; MORENO, L. et al. - The role of liver biopsy in the management of chronic hepatitis $\mathrm{C}$ in patients infected with the human immunodeficiency virus. Hum. Path., 35: 1083-1087, 2004.

21. RAMOS, B.; NUNEZ, M.; TORO, C. et al. - Changes in the distribution of hepatitis C virus $(\mathrm{HCV})$ genotypes over time in Spain according to HIV serostatus: implications for HCV therapy in HCV/HIV-coinfected patients. J. Infect., 54: 173-179, 2007.

22. RAMOS-PAES, C.; PASCUAL-CATALÁN, A.; ARAZO-GARCÉS, P.; AGUIRREERRASTI, J.M. \& LASIERRA, P. - Clinical implications of hepatitis C virus genotype in human immunodeficiency virus infected patients with chronic liver disease. Rev. clín. esp., 198: 212-216, 1998.

23. ROSENTHAL, E.; POIRÉE, M.; PRADIER, C. et al. - Mortality due to hepatitis Crelated liver disease in HIV-infected patients in France (Mortavic 2001 study). AIDS 17: 1803-1809, 2003

24. RUBIO-CACALLERO, M.; RUBIO-RIVAS, C.; NOGUES-BIAU, A. \& MANONELLESFERNÁNDEZ, A. - Epidemiology of chronic hepatitis $C$ virus in patients infected by human immunodeficiency virus. Study of 767 patients. Med. clín. (Barcelona) ,125(2): 56-58, 2005.

25. SEGURADO, A.C.; BRAGA, P.; ETZEL A. \& CARDOSO, M.R. - Hepatitis C virus coinfection in a cohort of HIV-infected individuals from Santos, Brazil: seroprevalence and associated factors. AIDS Patient Care STDS, 18: 135-143, 2004.

26. SORIANO, V.; PUOTI, M.; SULKOWSKI, M. et al. - Care of patients coinfected with HIV and hepatitis C virus: 2007 updated recommendations from the HCV-HIV International Panel. AIDS, 21: 1073-1089, 2007.

27. SULKOWSKI, M.S. \& BENHAMOU, Y. - Therapeutic issues in HIV/HCV-coinfected patients. J. viral Hepat., 14: 371-386, 2007.

28. UBERTI-FOPPA, C.; DE BONA, A.; GALLI, L. et al. - Liver fibrosis in HIV-positive patients with hepatitis $\mathrm{C}$ virus: role of persistently normal alanine aminotransferase levels. J. acquir. immune Defic. Syndr., 41: 63-67, 2006.

Received: 5 November 2007

Accepted: 3 July 2008 